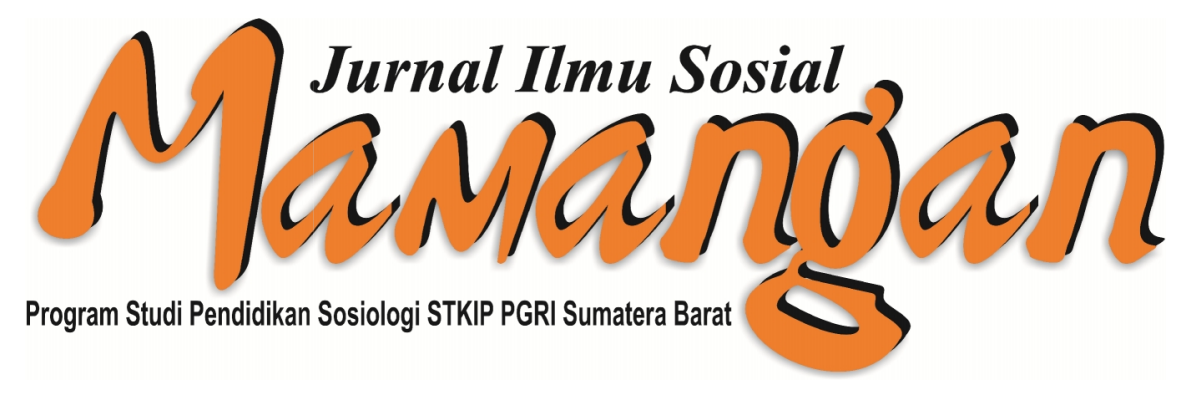

Jurnal Ilmu Sosial Mamangan

Volume 5, Nomor 1, Januari-Juni 2016

DAMPAK TRANSMIGRASI TERHADAP KEHIDUPAN SOSIAL MASYARAKAT: STUDI SEJARAH MASYARAKAT TIMPEH DHARMASRAYA

Penulis : Yosi Nova

Sumber : Jurnal Ilmu Sosial Mamangan, Volume 5, Nomor 1, Januari-Juni 2016

Diterbitkan Oleh : Laboratorium Pendidikan Sosiologi, STKIP PGRI Sumatera Barat

Untuk Mengutip Artikel ini :

Nova, Yosi, 2016. Dampak Transmigrasi Terhadap Kehidupan Sosial Masyarakat: Studi Sejarah Masyarakat Timpeh Dharmasraya. Jurnal Ilmu Sosial Mamangan, Volume 5, Nomor 1, Januari-Juni 2016: 23-36.

Copyright (C) 2016, Jurnal Ilmu Sosial Mamangan ISSN : 2301-8496 (Print), ISSN : 2503-1570 (Online) 


\title{
DAMPAK TRANSMIGRASI TERHADAP KEHIDUPAN SOSIAL MASYARAKAT: Studi Sejarah Masyarakat Timpeh Dharmasraya
}

\author{
Yosi Nova \\ STAI-YDI Lubuk Sikaping, Indonesia \\ Email : yosinova@yahoo.co..id
}

\begin{abstract}
Dharmasraya regency is once the destination of transmigration for Suamtera region. Some of them is Timpeh. The pattern of transmigration in Timpeh is general transmigration and local transmigration. Dharmasraya is of the most successful transmigration destination in Indonesia withTransmigration Award "Makarti Nayomata from the Indonesian minister of Transmigration in 2012 as indicator. This study conducted with qualitative research. Data collected through document study, interviews and observation. Result is the Dharmasraya transmigration program succesfull aired on nation TV station once year after. Transmigration program bring the changes on the social life of Timpeh. Transmigration conducted the new social identity, new culture and the pattern of economic development in Timpeh.
\end{abstract}

Keywords : Transmigration, Social Identity, Civil Society

\begin{abstract}
ABSTRAK
Kabupaten Dharmasraya adalah salah satu daerah tujuan transmigrasi untuk wilayah Sumatera. Di antara beberapa daerah yang berada dalam Kabupaten Dharmasraya yang menjadi daerah tujuan transmigrasi adalah Timpeh. Pola transmigrasi yang berlangsung di kecamatan Timpeh adalah Transmigrasi Umum (TU) dan Transmigrasi Lokal. Dalam menjalankan program transmigrasi yang diadakan oleh pemerintah, kabupaten Dharmasraya adalah contoh daerah tujuan transmigrasi yang paling berhasil di Indonesia, hal ini dibuktikan dengan penghargaan Transmigration Award "Makarti Nayomata" dari Mentri Tenaga Kerja dan Transmigrasi Republik Indonesia yang diraih oleh kabupaten Dharmasraya pada tahun 2012. Atas prestasi ini, maka tahun selanjutnya keberhasilan program transmigrasi di Kabupaten Dharmasraya juga ditayangkan di stasiun televisi nasional. Penelitian dilakukan secara qualitatif di nagari kecamatan Timpeh. Data dikumpulkan melalui studi dokumen, wawancara dan observasi. Hasil penelitian menunjukkan bahwa Program transmigrasi ternyata telah membawa banyak perubahan dalam berbagai bidang kehidupan masyarakat kecamatan Timpeh. Transmigrasi membentuk identitas baru sosial, budaya masyarakat serta pola pembangunan ekonomi.
\end{abstract}

Kata Kunci: Transmigrasi, Identitas Sosial, Civil Society 


\section{PENDAHULUAN}

Transmigrasi merupakan salah satu program pemerintah dalam rangka pemecahan masalah kependudukan, pemerataan pembangunan dan kesejahteraan (Hardjono, 1982). Transmigrasi dapat difahami sebagai perpindahan penduduk dari suatu wilayah yang padat penduduknya ke area wilayah pulau lain yang penduduknya masih sedikit atau belum ada penduduknya. Transmigrasi di Indonesia biasanya diatur dan didanai oleh pemerintah bagi warga yang umumnya golongan menengah ke bawah. Sesampainya di tempat transmigrasi para transmigran diberikan sebidang tanah pekarangan atau tanah pertanian untuk penunjang hidup di lokasi tempat tinggal yang baru.

Pemindahan penduduk ini sudah mulai dilaksanakan sejak zaman kolonial. Pemerintahan Indonesia baru mulai melanjutkan program ini dari tahun 1950. Program transmigrasi merupakan jalan yang ditempuh untuk mengatasi ketidakseimbangan dan ketitakmerataan penduduk. Program transmigrasi dianggap sebagai sarana pembangunan yang penting (Mochtar, 1978). Seiring dengan perkembangan pembangunan di daerah yang cukup pesat, dan juga perimbangan keuangan antara pusat dan daerah melalui kebijakan otonomi daerah, maka pulau-pulau yang tadinya menjadi tujuan program transmigrasi telah berkembang dan harus dibatasi penerimaan transmigran. Bahkan yang berkembang adalah penduduk pulau Sumatera sekarang menjadi obyek yang akan mengikuti program transmigrasi. Pemilihan lokasi transmigrasi juga harus berdasarkan asas kelestarian lingkungan hidup (utamanya hutan) (Asril, 2009).

Daerah tujuan transmigrasi di Indonesia meliputi Pulau Sumatera, Kalimantan, Sulawesi, dan Irian Jaya. Kabupaten Dharmasraya merupakan salah satu daerah tujuan transmigrasi di Pulau Sumatera. Di antara beberapa daerah yang berada dalam Kabupaten Dharmasraya sebagai daerah tujuan transmigrasi adalah daerah Timpeh. Pola transmigrasi yang berlangsung di kecamatan Timpeh adalah Transmigrasi Umum (TU) dan Transmigrasi Lokal.

Transmigrasi umum adalah program transmigrasi yang disponsori dan dibiayai secara keseluruhan oleh pihak pemerintah melalui Depnakertrans (Departemen Tenaga Kerja dan Transmigrasi). Mereka yang mengikuti transmigrasi umum, setelah tiba di daerah tujuan mendapat tanah pertanian seluas 2 hektar, rumah, bibit tanaman serta diberi jaminan makan untuk jangka waktu delapan bulan. Sementara itu transmigrasi lokal ialah perpindahan penduduk dalam satu daerah saja. Pindahnya bersifat setempat, misalnya dari satu provinsi ke provinsi yang lain, dan bahkan mungkin terjadi dalam satu provinsi.

Sebahagian besar penduduk Kecamatan Timpeh merupakan masyarakat transmigran. Berdasarkan data Disnakertrans Kab. Darmasraya transmigrasi ke daerah Timpeh melalui 7 tahap, yang dimulai sejak tahun 1982 hingga tahun 1995. Terhitung dari tahun awal program transmigrasi dijalankan untuk daerah Timpeh, maka jumlah masyarakat yang berhasil ditransmigrasikan ke daerah ini mencapai 2.568 kepala keluarga yang berasal dari berbagai daerah yaitu, Jawa Barat, Jawa Timur, Yogyakarta, dan transmigrasi lokal (BPS, 1984)

Berdasarkan profil Kecamatan Timpeh tahun 2009, sebelum datangnya masyarakat transmigrasi, daerah Timpeh terdiri dari hutan belantara dan penduduknya hanya sedikit, selain itu mereka masih keterbelakangan baik itu dalam pendidikan, ekonomi, dan maupun pembangunan. Transmigrasi telah mendorong munculnya perubahan sosial di daerah ini. Kecamatan Timpeh juga merupakan Kecamatan hasil penataan dan pembentukan kecamatan sesuai dengan Peraturan Daerah Kabupaten Dharmasraya no. 3 tahun 2008 yang awalnya bagian dari Kecamatan Sitiung Kabupaten Dharmasraya berdiri secara resmi pada tanggal 10 Desember 2008.

Kemajuan untuk daerah Timpeh ini bisa dilihat dalam berbagai bidang di antaranya dalam bidang keagamaan, dalam bidang ini dapat dilihat dengan banyaknya jumlah Mesjid, Mushalla, dan Langgar sebagai sarana tempat peribadatan, didirikan beberapa lembaga pendidikan formal seperti, yayasan al-Muhajirin, pondok pesantren Miftahul 'Ulum, beserta Madrasah Diniyyah Awaliyyah (MDA), Taman Pendidikan Qur'an (TPQ) dan Taman Pendidikan Sahril Qur'an (TPSQ). Selain itu juga diadakannya beberapa kegiatan pendidikan non formal seperti, 
wirid yasinan, remaja mesjid, dan majelis ta'lim. Semangat keagamaan masyarakat Timpeh juga ditandai dengan semakin banyaknya masyarakat Timpeh yang naik haji dan setiap bulan Ramadhan diadakan acara santunan untuk anak-anak yatim.

Dalam bidang perekonomian penghasilan masyarakat Timpeh diperoleh dari tanaman kelapa sawit dan karet. Perkembangan perekonomian masyarakat Timpeh dimulai dari tahun 1994 karena pada tahun ini diadakan penanaman kelapa sawit besar-besaran sehingga menghasilkan perekonomian yang sangat stabil dan pada umumnya mereka sudah bisa memenuhi kebutuhan hidup mereka dengan baik.

Bidang pendidikan juga mendapat perhatian yang sangat baik dari masyarakat Timpeh. Hal itu dapat diketahui dengan berdirinya beberapa sekolah tingkat PAUD, TK, SDN, SMPN, dan SMAN. Sedangkan dalam hubungan sosial, baik itu dari masyarakat asli dan masyarakat transmigran terjalin relasi hubungan yang baik dan nyaris tidak ada konflik antar kelompok.

Ulasan di atas merupakan gambaran secara umum yang ada di kecamatan Timpeh. Dengan adanya program transmigrasi ini, telah membawa banyak perubahan dan perkembangan untuk kecamatan Timpeh. Dalam menjalankan program transmigrasi yang diadakan oleh pemerintah, kabupaten Dharmasraya dijadikan sebagai contoh daerah yang paling berhasil di Indonesia, sehingga pada tahun 2012 Dharmasraya meraih Transmigration Award "Makarti Nayomata" dari Menteri Tenaga Kerja dan Transmigrasi Republik Indonesia atas dedikasinya mensukseskan program transmigrasi tersebut. Prestasi ini ditayangkan selama setengah jam oleh salah satu stasiun TV Nasional. (Harian Umum Rakyat Sumbar, 2014)

Berdasarkan latar belakang tersebut maka menjadi fenomena yang menarik untuk melihat perubahan sosial masyarakat Timpeh sebagai konsekuensi logis dari adanya transmigrasi di daerah tersebut. Karena pada umumnya masyarakat transmigran dipenempatan transmigrasi lainnya mempunyai hubungan yang kurang baik dengan masyarakat asli. Hal itu biasanya disebabkan oleh beberapa faktor di antaranya perebutan lahan pertanian, perbedaan budaya, perbedaan pemahaman keagamaan, dan lain sebagainya.

Penelitian tentang kehidupan masyarakat transmigran memang telah dilakukan oleh beberapa peneliti, namun bukan dalam arti kata bisa mewakili seluruh konteks kehidupan masyarakat transmigran diberbagai wilayah di Indonesia. Berdasarkan hasil penelusuran penulis, ada beberapa penelitian yang berkaitan dengan kehidupan masyarakat transmigran yang dapat dijadikan sebagai acuan dalam penulisan pembahasan ini.

Suatu penelitian tentang Komunikasi Penengah Budaya yang dilakukan oleh Wakidul Kohar, dan penelitian ini telah dibukukan pada tahun 1997. Penelitian ini beranjak dari asumsi bahwa dibalik pergumulan keragaman etnis dalam suatu wilayah, sangat dimungkinkan terjadi sentimen-sentimen kesukuan, kedaerahan, dan agama. Dalam pembahasan ini ia melihat kepada konflik yang terjadi antara masyarakat asli Minangkabau dan masyarakat transmigran dari Jawa di daerah Lunang Silaut (Pesisir). Menurut hasil penelitiannya ada dua faktor yang menyebabkan terjadinya konflik antara dua etnis budaya ini yaitu faktor tanah dan faktor perbedaan pemahaman keagamaan (Kohar, 2010).

Selanjutnya buku Transmigrasi di Indonesia: Rigkasan Tulisan dan Hasil-hasil Penelitian yang disunting oleh Arif Budiman. Buku ini merupakan ringkasan tulisan-tulisan yang tersebar di berbagai koran, majalah, laporan penelitian, dan beberapa buku yang membahas tentang transmigrasi. Pembahasan pertama yang disajikan dalam buku ini ialah mengenai sejarah transmigrasi di Indosesia. Pada tahap awal program ini dimotori oleh pemerintahan Kolonial Belanda yang disebut dengan istilah kolonisasi sampai berkembang menjadi istilah transmigrasi setelah Indonesia merdeka. Selanjutnya buku ini membahas tentang berbagai macam pola transmigrasi yang pernah berkembang di Indonesia mulai dari pola transmigrasi pertanian, transmigrasi umum, transmigrasi Swakarsa, Transmigrasi Pola Perkebunan, Pola Nelayan, dan Pola Industri. Tulisan ini merupakan salah satu bentuk usaha yang dilakukan oleh penulis dalam mencari pemecahan berbagai masalah transmigrasi yang ada di Indonesia (Budiman, 1985). 
Rukmadi Warsito dkk membahas tentang Transmigrasi: dari Daerah Asal sampai Benturan Budaya di Tempat Pemukiman. Tulisan ini membicarakan tentang berbagai permasalahan yang dihadapi oleh masyarakat transmigran di daerah penempatan, mulai dari masalah pertanahan, perekonomian, sampai kepada masalah sosial-budaya. Selain itu dalam penulisan tersebut para penulis juga memberikan semacam rekomendasi atau saran kepada pemerintah dan masyarakat transmigran untuk menyelesaikan berbagai permasalahan yang dihadapi oleh masyarakat transmigran tersebut (Warsito, 1984).

Dapat dilihat beberapa penelitian yang dicantumkan di atas telah menghasilkan beberapa pendekatan dalam melihat kehidupan masyarakat transmigran di antaranya menggunakan pendekatan antropologi, sosiologi, ekonomi dan pendekatan keagamaan. Dengan demikian penelitian sejarah ini menggunakan pendekatan sejarah sosial dengan titik persoalan yang berbeda dengan penelitian sebelumnya.

Tulisan ini akan menitikberatkan pengkajian pada tingkat kemakmuran kehidupan masyarakat Timpeh dan faktorfaktor yang mempengaruhinya. Pembahasan akan mencakup peranan masyarakat transmigran dalam kehidupan sosial masyarakat Timpeh dan perubahanperubahan yang terjadi di kecamatan Timpeh setelah kedatangan transmigran.

\section{METODOLOGI PENELITIAN}

Penelitian ini merupakan penelitian sejarah terkait dengan perubahan sosial masyarakat Timpeh. Mengingat kajian penelitian ini dilakukan untuk mengungkap dampak transmigrasi maka, kondisi masyarakat Timpeh sebelum dan sesudah transmigrasi juga ditampil. Kondisi itu meliputi aspek budaya, agama, pendidikan dan ekonomi. Untuk mendapatkan fakta-fakta yang lebih akurat, penelitian ini menggunakan metode penelitian sejarah yakni penelitian terhadap sumber-sumber sejarah secara kritis. Untuk menjangkau sumber secara lebih luas dan kritis maka penelitian ini menggunakan pendekatan kualitatif.
Langkah pertama adalah mencari dan mengumpulkan sumber-sumber yang relevan dengan topik dan judul penelitian, sejarah sosial masyarakat Timpeh. Sumber yang digunakan untuk mendapatkan fakta tentang kehidupan sosial di daerah ini, diarahkan pada arsip-arsip pemerintah daerah sebagai sumber primer, terutama yang menyangkut tentang berbagai kebijakan pemerintah terhadap kehidupan masyarakat transmigran. Selain sumber pemerintahan akan dilengkapi dengan sumber lisan dalam bentuk wawancara dengan berbagai tokoh masyarakat yang di anggap berkompeten untuk memberikan Informasi sekitar masalah yang diteliti.

Sementara itu sumber-sumber tertulis lainnya merupakan bentuk sumber sekunder. Sumber ini terdiri dari tulisan-tulisan yang menyangkut kehidupan sosial masyarakat transmigrasi. Surat-kabar meskipun dengan tidak kredibilitas yang memerlukan pengujian yang ketat, namun sangat membantu melengkapi sumber bagi penelitian ini.

Sumber-sumber ini didapat melalui penelitian lapangan (field research) dan kepustakaan (library research). Fieldresearch dilakukan dengan wawanacara kepada beberapa nara sumber terkait pokok pembahasan. Dalam kajian sejarah hal ini dikenal sebagai sejarah lisan (oralhistory). Sedangkan untuk persiapan penelitian lapangan dalam melakukan observasi dan wawancara peneliti menyediakan peralatan, seperti kamera, buku catatan dan sarana penunjang lainya. Kemudian masih dalam tahapan pengumpulan data, observasi lapangan dilakukan dengan jalan mengadakan wawancara kepada beberapa orang tokoh masyarakat, tokoh agama, masyarakat transmigrasi umum, transmigrasi lokal dan masyarakat asli. Pengumpulan sumber juga dilakukan melalui studi kepustakaan (library research) yaitu dengan mempelajari dan mengumpulkan sumbersumber tertulis berupa buku-buku, artikel, dokumen dan arsip yang terkait dengan topik penelitian.

Setelah sumber-sumber terkumpul maka dilakukan pengujian terhadap sumbersumber tersebut. Dalam penelitian sejarah langkah ini lazim disebut sebagai kritik sumber. Langkah ini dilakukan dengan mengkritisi isi informasi yang disampaikan 
oleh masyarakat mengenai hal-hal yang berkaitan dengan kehidupan sosial masyarakat Timpeh setelah datangnya masyarakat transmigran. Kritik yang dilakukan di sini salah satunya adalah mengecek isi dan informasi yang disampaikan dalam sumber-sumber yang telah ditemukan dengan mengkolaborasikan antara sumber satu dengan sumber lainnya yang memiliki kesamaan informasi.

Langkah selanjutnya adalah menginterprestasi atau melakukan penafsiran sejarah dengan analisis sejarah. Langkah ini merupakan kegiatan menafsirkan dan menganalisa beberapa keterangan dari sumber-sumber data sejarah sosial keagamaan masyarakat teransmigran Timpeh. Baik itu data-data yang diperoleh melalui wawancara dan maupun data yang diperoleh dari berbagai literatur. Pada langkah ini sumber dikelompokkan berdasarkan pertimbangan urutan waktu, tempat dan aspek lainnya. Kemudian antara sumber yang satu dengan sumber yang lainnya dirangkai untuk mencari hubungan antara satu fakta dengan fakta yang lain.

$$
\text { Langkah terakhir adalah }
$$
mengeksplanasikan hasil penelitian dalam bentuk tulisan. Langkah ini merupakan usaha atau tindakan mendeskripsikan, memaparkan, menuliskan atau melaporkan hasil penelitian yang telah dilakukan, dalam hal ini yang berhubungan dengan topik sejarah sosial masyarakat Timpeh.

\section{LATAR BELAKANG TRANSMIGRASI KE TIMPEH}

Indonesia merupakan negara yang mempunyai jumlah penduduk cukup banyak, sehingga sejak pemerintahan Kolonial Belanda diadakan program pengurangan dan penyeimbangan jumlah penduduk Pulau Jawa dan pulau-pulau lainnya, program ini diawali sejak tahun 1905 hingga sesudah Indonesia merdeka program perindahan penduduk tetap dilanjutkan. Program ini dilandasi dengan tujuan pemerataan dan keterpaduan antara pembangunan nasional dan regional. Secara ideal tujuan pembanguaan yang dimaksud akan membawa perubahan pertumbuhan daerah, baik daerah asal mapun daerah penerima (Swasono \& Singarimbun, 1985).

Saat pemerintahan Soekarno kondisi
Indonesia belum cukup stabil baik dalam bidang sosial, ekonomi, dan maupun politik, usaha perpindahan penduduk tetap diprogramkan namun berjalan tidak stabil. Masalah pengurangan jumlah penduduk mendapat perhatian yang cukup besar ketika jabatan presiden pindah ke tangan Soeharto, ini dibuktikan dengan diadakannya program Keluarga Berencana (KB) tahun 1968 dan transmigrasi (Budiman, 1985). Transmigrasi dengan daerah tujuan Kecamatan Timpeh mempunyai dua bentuk yaitu transmigrasi umum dan transmigrasi lokal.

\section{Transmigrasi Umum}

Transmigrasi umum adalah program transmigrasi yang disponsori dan dibiayai secara keseluruhan oleh pemerintah melalui Depnakertrans (Departemen Tenaga Kerja dan Transmigrasi). Transmigran umum untuk daerah Timpeh berasal dari berbagai daerah di antaranya, Jawa Barat, Jawa Timur, dan Yogyakarta. Adapun latar belakang masyarakat transmigran tersebut didominasi oleh faktor ekonomi yang sangat sulit dan tanah yang sangat sempit di daerah asal mereka.

Kemelaratan yang terjadi di Pulau Jawa dulu merupakan suatu masalah, dan usaha untuk memeranginya yaitu dengan memindahkan penduduk. Semua itu diadakan secara kuantitatif tanpa memikirkan segi kualitatif, sehingga peledakan penduduk tidak terkendalikan dan mengakibatkan ancaman kehancuran ekologis serta bertambahnya kemelaratan (Subangun, 1980). Usaha untuk memindahkan penduduk sudah sejak zaman dahulu dilaksanakan dan dari tahun ke tahun selalu mendapat perhatian, akan tetapi masalah keseimbangan belum juga dapat diselesaikan (Suroso, 1981).

Ekonomi yang sangat sulit telah membuat masyarakat jenuh, sehingga ketika adanya tawaran dari pemerintah untuk mengadakan program transmigrasi pada tahun 1982, banyak masyarakat yang tertarik untuk mengikuti program tersebut. Apa lagi pemerintah mengiming-imingi masyarakat dengan berbagai fasilitas, seperti tanah, rumah, jaminan makan 
selama satu tahun, dan lain-lain sebagainya, membuat masyarakat yang kurang mampu semakin yakin untuk mengikuti program transmigrasi tersebut.

Selain itu pemerintah juga memperlihatkan foto-foto keberhasilan masyarakat yang mengikuti program transmigran pada tahun-tahun sebelumnya. Selain itu, pemerintah juga memperlihatkan foto-foto daerah kemana mereka akan ditransmigrasikan. Sehingga banyak masyarakat yang mendaftarkan diri untuk mengikuti program transmigrasi tersebut. Mereka berharap dengan mengikuti program transmigrasi ini bisa membuat hidup mereka lebih baik dan sejahtera.

Masyarakat yang siap untuk diberangkatkan ke daerah tujuan transmigrasi dijemput oleh pemerintah ke rumah masing-masing dan didanai seluruh biaya transportasi yang akan membawa mereka ke daerah baru tersebut. Masyarakat diberangkatkan dengan pasawat ke Sumatera Barat, setelah itu dihantarkan ke Kabupaten Sawah Lunto-Sijunjung. Kedatangan mereka disambut langsung oleh pemerintahan Kabupaten. Setelah selesainya acara penyerahan dan penerimaan masyarakat transmigrasi tersebut, barulah para transmigran dihantarkan ke daerah Timpeh dengan menggunakan mobil Loging.

Setibanya di daerah Timpeh maka masyarakat transmigran tersebut mulai mencari rumahnya masing-masing dengan nomor yang telah ditentukan oleh pemerintah. Selama satu minggu masyarakat transmigran diberi makan siap saji, untuk itu setiap jam makan para transmigran akan antri menunggu jatah makan. Kemudian setelah dianggap efektif untuk mandiri barulah pemerintah menyerahkan alat-alat dapur secukupnya, pakaian, dan lahan untuk perkebunan sebesar 2 hektar per kepala keluarga. Hal ini bertujuan agar masyarakat mandiri dan mampu mengolah sendiri perkebunan yang disediakan untuk menopang ekonomi keluarga.

\section{Transmigrasi Lokal}

Transmigrasi lokal dapat dipahami dengan perpindahan penduduk dalam satu daerah saja. Pindahnya bersifat setempat, misalnya dari satu provinsi ke provinsi yang lain, dan bahkan mungkin terjadi dalam satu provinsi. Transmigrasi lokal di Kecamatan Timpeh paling dominan berasal dari Kabupaten 50 Kota.

Terjadinya transmigrasi masyarakat Kabupaten 50 Kota, tepatnya dari Desa Taratak (Payakumbuh) ke darah Timpeh disebabkan terjadinya bencana alam yang melanda daerah tersebut pada tahun 1993. Longsor yang melanda daerah Taratak menyebabkan hampir sebagian daerah ini habis dan hancur berantakan, sehingga tidak mungkin lagi untuk ditempati. Peristiwa ini mendapat perhatian dari pemerintah, banyak pejabat-pejabat yang datang tidak terkecuali Menteri Sosial Indonesia. Hasan Basri Durin selaku Gubernur Sumatera Barat memberikan pengarahan bahwa Desa Taratak tidak layak lagi dijadikan kediaman masyarakat. Kemudian Hasan Basri memberikan alternatif supaya masyarakat Taratak dipindahkan ke daerah lain.

Setelah diadakan pendataan terhadap lahan masyarakat Taratak yang lahannya tidak layak digunakan lagi maka hasilnya menunjukkan lebih kurang 250 kepala keluarga harus dipindahkan ke tempat yang aman dan tidak rawan bencana. Dibentuk Koordinator Korban Bencana Alam Kabupaten 50 Kota untuk program Transmigrasi supaya membuat usulan kepada pemerintah Kabupaten 50 Kota agar masyarakat Desa Taratak dipindahkan ke daerah lain. Inisiatif ini ditanggapi oleh Pemerintah setempat dan pemerintah setuju dengan hal tersebut.

Walaupun sudah disepakati, namun perjalanan transmigrasi Desa Taratak sempat gagal sampai 2 kali. Tahap pertama digagalkan karena pemerintahan Kabupaten 50 Kota berinisiatif untuk memberikan ganti rugi kepada masyarakat yang tanahnya dilanda bencana longsor, dengan syarat 
program transmigrasi untuk daerah ini digagalkan. Namun beberapa dari masyarakat yang ingin mengikuti program transmigrasi tidak menyetujui hal tersebut. Karena adanya tuntutan dari masyarakat supaya program transmigrasi tetap dilanjutkan, akhirnya pemerintah setempat mengalah dan bersedia melanjutkan program transmigrasi, namun hanya bagi masyarakat yang ingin ikut saja. Sedangkan bagi masyarakat yang layak transmigrasi tetapi tidak ingin mengikuti program tersebut, maka diberi ganti rugi uang sebesar 1.000.000 rupiah oleh pemerintah per kepala keluarga.

Dari $250 \mathrm{kk}$ yang telah terdaftar yang layak diberangkatkan ke daerah penempatan transmigrasi, namun yang berangkat hanya $75 \mathrm{kk}$, selebihnya memilih untuk tetap tinggal di Desa Taratak dan menerima uang ganti rugi dari pemerintah. Sementara untuk masyarakat yang siap untuk ditransmigrasikan diberangkatkan pada tanggal 9 Juni 1994. para transmigran diberangkatkan ke daerah penempatannya yaitu di Nagari Timpeh, tepatnya di SP 7-Desa Tabek. Setibanya dilokasi penempatan para transmigran diberi satu rumah dengan luas perkarangan $1 / 2$ hektar oleh pemerintah, selain itu diberi alat-alat perlengkapan seperti, makan selama tiga hari, pakaian seadanya, alat perlengkapan dapur, beserta alat-alat perkebunan melalui KUPT (Kantor Unit Penempatan Transmigrasi). Selepas dari 3 hari maka para transmigran diberikan alat dapur seperti, beras, minyak, sabun, lauk-pauk, dan diberi jaminan makan selama 1 tahun.

Kemudian masyarakat transmigrasi Payakumbuh dianjurkan untuk menggarap hutan yang akan dijadikan sebagai lahan perkebunan mereka secara gotong royong, setelah hutan-hutan digarap barulah diadakan pencabutan lot, tiap-tiap orang mendapatkan tanah seluas 2 hektar, penempatannya berdasarkan nomor lot yang didapatkan. Kemudian barulah dilepaskan oleh pemerintah untuk hidup madiri, maka para transmigran harus berusaha sendiri dengan menggarap lahan yang telah dibagikan dan ada juga yang bekerja di perusahaan dan diberi gaji pada setiap harinya, ketika itu perusahaan yang ada ialah PT. Ingkasa Raya.

Selain transmigrasi lokal yang berasal dari Kabupaten 50 Kota, juga ada dari daerah Padang Si Busuk (Kabupaten Sawah Lunto-Sijunjung) dan Kabupaten Solok. Latar belakang transmigrasi masyarakat tersebut disebabkan karena sulitnya perekonomian, di daerah asal sehingga tidak memadai untuk memenuhi kebutuhan hidup mereka. Maka itu ketika adanya tawaran untuk mengikuti program transmigrasi dari pemerintah, banyak masyarakat yang ingin mengikuti, karena mereka sangat mengharapkan dengan mengikuti program transmigrasi ini bisa mengubah status ekonomi yang lebih baik.

Program transmigrasi dengan daerah tujuan Timpeh dimulai sejak tahun 1982 berakhir tahun 1995. Secara keseluruhan jumlah kepala keluarga yang berhasil dipindahkan dari berbagai daerah asal ke Kecamatan Timpeh mencapai 2.768 kepala keluarga.

\section{IDENTITAS BARU MASYARAKAT TRANSMIGRAN}

Penduduk Kecamatan Timpeh terdiri dari beberapa etnis atau suku bangsa seperti, penduduk asli Minangkabau, Jawa (eks transmigrasi), dan Sunda (eks transmigrasi). Walaupun mereka berasal dari etnis yang berbeda namun tetap terjalin hubungan yang cukup baik antara masyarakat asli dan pendatang. Terjalinnya hubungan persaudaraan yang kokoh ternyata sesuai dengan pepatah adat Minangkabau mengatakan "dimano bumi dipijak disitu langik dijunjuang." Baik masyarakat transmigrasi asal dari pulau Jawa atau adatistiadatnya berbeda dengan adat Minangkabau berusaha untuk menyesuaikan diri dengan adat Minangkabau yang merupakan adat yang dipangku oleh masyarakat Timpeh.

Semua warga transmigrasi menjadi anak kemenakan dari Ninik Mamak daerah yang di tempati. Mengaku induak dianjurkan kepada masyarakat transmigrasi asal pulau Jawa kepada Ninik Mamak yang memimpin persukuan yang ada di daerah Timpeh, sesuai 
dengan kata adat "kok jauah manjalang suku, kok dakek manjalang mamak, adat samo diisi, limbago samo dituang, kok ka bukik samo mandaki, kalurah samo manurun." Adapun suku-suku asli yang dianut oleh masyarakat Timpeh ialah, Melayu, Melayu Tongah, Melayu Domo, Melayu Dalam, Piliang Godang, Piliang Soni, dan Patopang.

Para transmigrasi dibebaskan kemana ia harus berinduk, sehingga pada umumnya masyarakat transmigrasi yang tidak berasal dari Minangkabau mendapatkan suku. Oleh sebab itu mereka harus mengikuti semua ketentuan-ketentuan adat istiadat Minangkabau. Misalnya, masyarakat Minangkabau menganut sistem kekerabatan matrilineal, yakni kekerabatan yang menarik garis kekerabatan menurut garis ibu. Menurut sistem ini seorang anak harus masuk dalam keluarga ibunya. Sementara seorang ayah mempunyai wewenang yang tidak terlalu kuat dalam mengatur keluarganya. Laki-laki di rumah keluarga istrinya dalam terminologi Minangkabau disebut dengan urang sumando (Hasan, 1988). Anak laki-laki sesudah akilbalig dipisahkan dari ibunya dan harus tidur di surau, walaupun akhir-akhir ini budaya tersebut sudah jarang ditemukan. Namun yang masih tetap adalah setelah laki-laki menikah dia harus tinggal di rumah istrinya (Salmadanis \& Samad, 2003).

Tentu saja untuk masyarakat etnis Jawa ketentuan ini tidak berlaku sepenuhnya, hanya saja mereka mengikuti beberapa ketentuan seperti, garis kekerabatan berdasarkan menurut garis ibu, dan tidak dibolehkan kawin satu suku. Selain mengikuti adat Minagkabau masyarakat transmigran asal Pulau Jawa yang sudah mengaku berinduk dan bersuku, juga dipercaya dalam membantu kepemimpinan suatu suku. Adapun struktur kepemimpinan satu suku terdiri dari berbagai jabatan yaitu, Datuak, Monti, Dubalang, Bundo Kanduang, dan Alim Ulama. Untuk daerah ini ada beberapa kepemimpinan suku yang dipercayakan kepada masyarakat etnis Jawa misalnya, kepemimpinan Alim Ulama, selain itu juga dipercayakan sebagai Panungkek Datuak (pendamping datuk) dalam suatu suku.

Pemberian gelar adat (baca: Panungkek Datuak) kepada etnis Jawa sesungguhnya merupakan anomali terhadap adat Minangkabau. Sebab, gelar tersebut hanya dapat diberikan atau disandang oleh keturunan orang Minangkabau. Besar kemungkinan, pemberian gelar itu bukan artian pusako adat Minangkabau tetapi sebatas formalitas belaka. Sebagai syarat atau pengakuan menjadi masyarakat Minang. Hal itu menunjukkan bahwa identitas masyarakat transmigran -jawa dan madura- yang awalnya menganut patrilineal (kekerabatan berdasarkan ayah) berubah menjadi matrilineal. Meski dalam praktek sosial dan wilayah privat identitas itu tetap bertahan. Hal itu dapat dilihat dari realitas tradisi dan kesenian yang terdapat di tengah-tengah masyarakat. Masing-masing etnis yang mendiami daerah Timpeh dengan kesenian yang berbeda-beda bebas melakukan pertunjukannya bahkan mendapat dukungan dari warga sesama transmigran. Etnis Minangkabau misalnya mempunyai kesenian seperti Randai, Saluang, dan Rabbana, etnis Jawa sangat diidentikkan dengan kesenian Kuda Lumping dan Reok Ponorogo, sementara etnis Sunda sangat terkenal dengan Tari Jaipongnya. Terjadinya hubungan interaksi antar budaya yang baik antar etnis tersebut telah menyebabkan terjadinya asimilasi budaya untuk daerah ini. Kesenian-kesenian tersebut akan ditampilkan dalam berbagai acara seperti, acara pesta pernikahan, sunatan, dan lain-lain sebagainya.

Beberapa kesenian terkadang dimainkan oleh orang yang bukan berasal dari etnis tersebut. Dapat ditemukan beberapa orang yang berasal dari etnis Jawa ternyata mahir dalam menari Pasambahan yang berasal dari kesenian Minangkabau. Dalam acara pertukaran jabatan pengurus adat Minagkabau di Timpeh biasanya diawali dengan tari Pasambahan ternyata masyarakat Timpeh yang bukan berasal dari etnis Minangkabau juga sangat antusias dalam menyambut acara tersebut, ini dibuktikan dengan kegigihan mereka untuk belajar menari Persembahan yang akan ditampilkan dalam acara tersebut. Begitu juga dengan etnis Minangkabau ketika mengadakan acara baralek dan sunatan mereka sering mengadakan pertunjukan Kuda Lumping untuk memeriahkan acara tersebut. Hal ini telah menimbulkan rasa saling memiliki antara satu dan yang lainnya.

Demikian pula halnya dengan tradisi yang berkaitan dengan perkawinan, 
masyarakat Minangkabau, Jawa, dan Sunda memiliki perbedaan dalam pelaksanaannya dan cenderung menggunakan tradisi budaya masing-masing. Hanya saja sebelum melangsungkan acara kegiatan adatnya mereka dianjurkan untuk melaporkan atau memberitahu Ninik Mamak. Begitu juga dalam acara kematian, sunatan, akikah dan lain-lain sebagainya.

Dalam masyarakat yang dinamis, konflik adalah keniscayaan. Keniscayaan itu mengejawantah dalam berbagai pola interaksi dan relasi individu dan kelompok yang ada dalam masyarakat (Firdaus, 2014). Namun, di masyarakat timpeh keniscayaan tersebut tidak terjadi. Hal ini disebabkan oleh pertemuan budaya dan tradisi dalam masyarakat serta adanya indentitas bersama, maka kehidupan masyarakat menjadi aman dan tentram. Antar masyarakat yang berbeda etnis tersebut nyaris tidak terjadi konflik antar kelompok, masyarakat berusaha untuk memahami budaya masing-masing, sehingga muncullah hubungan sosial yang harmonis. Karena terjalinnya hubungan yang harmonis antara masyarakat yang berbeda etnis tersebut, telah menciptakan persatuan yang kokoh, sehingga membawa banyak perkembangan untuk daerah ini, diantaranya dalam bidang keagamaan, ekonomi, pembangunan, dan lain sebagainya. Kerjasama antara etnis menjadikan masyarakat saling terintegrasi antara satu sama lain karena saling ketergantungan (Firdaus, 2012)

Terciptanya hubungan sosial yang baik di antara etnis yang berbeda budaya tersebut tidak bisa dilepaskan dari peran interaksi. Hal ini menunjukkan bahwa integrasi dapat berlangsung melalui interaksi yang baik dan inten melalui struktur sosial yang ada (Rahmad, 2015) Interaksi ini terjadi dalam berbagai bidang; pertama, perkawinan antar etnis, anggota kelompok etnis Minang pribumi dan etnis Jawa di wilayah ini pada awalnya tidak mempunyai keinginan untuk menjalin hubungan keluarga dekat. Namun dengan berjalannya waktu dan terjadinya interaksi antara anak-anak mereka sehingga menyebabkan terjadilah pernikahan antar etnis tersebut. Perkawinan antar etnis mencapai $15 \%$ pada setiap tahun di seluruh wilayah Kecamatan Timpeh. Namun yang paling banyak melakukan pernikahan antar etnis ini ialah etnis Minang pendatang dangan etnis Jawa, melalui pernikahan ini maka akan melahirkan anak-anak keturunan MinangJawa. Pernikahan antar etnis telah membuka interaksi yang terbuka antara keluarga yang berbeda etnis tersebut.

Kedua, perekonomian, etnis Jawa terkenal sebagai orang yang suka bekerja keras sehingga sebahagian besar mereka berprofesi sebagai petani kelapa sawit dan karet, mereka terkenal dengan orang-orang yang tekun dalam bekerja. Tidak jarang etnis Minangkabau lebih suka mempekerjakan orang-orang Jawa dalam berbagai usaha yang digelutinya, Kebanyakan orang minangkabau berprofesi sebagai pedagang terjadinya transaksi jual beli antar etnis telah memberikan kesempatan untuk melakukan interaksi yang baik antara beberapa etnis. Untuk mamajukan dalam bidang perekonomian dalam sektor pertanian masyarakat Timpeh membentuk kelompok tani, dalam kelompok ini etnis manapun dibolehkan untuk bergabung menjadi anggota kelompok, sehingga kelompok tani ini telah membantu dalam melancarkan interaksi antar etnis tersebut. Ketiga, politik, para transmigrasi yang berasal dari berbagai daerah tersebut tidak hanya berperan dalam kehidupan sosial kemasyarakatan, ternyata para imigran ini juga mampu berlomba dalam bidang perpolitikan, hal ini bisa dibuktikan hampir sebahagian besar pejabat kecamatan dan kenagarian di daerah Timpeh berasal dari imigran baik yang berasal dari etnis Jawa maupun Minangkabau. Dunia politik juga telah menciptakan terjalinnya interaksi yang baik antar etnis karena telah munculnya sikap saling mempercayai antara satu dan lainnya. Keempat, agama, kehidupan keagamaan dalam masyarakat dipimpin oleh seorang tokoh yang dianggap mumpuni dalam berbagai bidang keagamaan. Umumnya setiap ritual adat yang dijalankan oleh masing-masing etnis tidak bisa dilepaskan dari peran agama, misalnya dalam acara pernikahan, khitanan, sukuran, dan lain-lain sebagainya selalu disertai do'a bersama. Ternyata bidang keagamaan berperan sangat penting dalam hubungan antara etnis tersebut, hal ini disebabkan oleh agama yang dianut oleh masyarakat setempat dan para imigran sama-sama agama Islam. Walaupun ada perbedaan pemahaman dalam praktek keagamaan namun mereka tetap tidak saling memojokkan. 
Terjalinnya hubungan baik antara etnis tersebut telah mendorong terjadinya perubahan-perubahan yang lebih cenderung kepada kemajuan. Adapun perubahanperubahan tersebut;

\section{Perekonomian}

Kondisi ekonomi mayarakat asli Timpeh sebelum datangnya masyarakat Transmigran sangat tidak stabil, karena masyarakat Timpeh masih hidup dalam kelompok kecil dan baru berpenghasilan dari tanaman karet dan hasil pecarian rotan. Untuk menjual hasil dari pekerjaan mereka sangatlah susah, karena para petani harus menjualnya ke daerah Sitiung. pada masa itu belum ada transportasi untuk mencapai daerah ini, para petani harus berjalan kaki dan bisa menghabiskan waktu satu hari untuk sampai ke daerah Sitiung tersebut.

Awal kedatangan masyarakat transmigrasi tahap pertama, kehidupan masyarakat tetap masih dalam kesulitan, mereka hanya berpenghasilan dari hasil perkebunan dengan seadanya. Masyarakat transmigran yang memiliki modal maka banyak yang menjadi pedagang, namun bagi yang tidak memiliki modal mereka harus bersusah payah untuk menggarap lahan perkebunan yang baru saja dibagikan oleh pemerintah. Kedatangan masyarakat transmigrasi telah menyulap daerah Timpeh pada tahap awal dipenuhi dengan hutan mulai digarap untuk dijadikan lahan pertanian. Pembukaan lahan secara besarbesaran bertujuan untuk ditanami bibit kelapa sawit, tepatnya pada tahun 1994.

Hingga sekarang pada umumnya masyarakat Timpeh berpenghasilan dari perkebunan kelapa sawit. Selain perkebunan kelapa sawit, masyarkat Timpeh juga berpenghasilan dari hasil perkebunan karet, sawah, kebun, berdagang, perikanan (kolam dan keramba) dan binatang tersenak seperti, kerbau, sapi, kambing dan unggas. Akan tetapi hampir $70 \%$ masyarakat Timpeh berprofesi sebagai petani kelapa sawit. Untuk memajukan usaha pertanian tersebut maka dibentuklah beberapa kelompok tani untuk bekerja di perkebunan dan sawah, sementara pemerintah membantu dalam menyediakan bibit dan pupuknya. Lahirnya Kelompok tani ini dilatar belakangi oleh beberapa faktor diantaranya, karena banyaknya petani di daerah Timpeh, belum adanya wadah atau organisasi yang mengurus kepentingan dan kebutuhan petani, serta didorong oleh timbulnya kesadaran masing-masing anggota untuk meningkatkan mutu yang lebih baik. Untuk Kecamatan Timpeh kelompok tani terbagi 2 bahagian yaitu, kelompok tani kelapa sawit dan kelompok tani sawah, adapun kelompok tani yang terdapat di Kecamatan Timpeh berjumlah sebanyak 79 kelompok.

\section{Pendidikan}

Daerah Timpeh sebelum datangnya masyarakat transmigrasi belum mempunyai sarana atau tempat pendidikan. Masyarakat Timpeh yang ingin bersekolah harus melalui perjuangan yang sangat panjang, karena pada masa itu masyarakat Timpeh menuntut ilmu ke daerah Sitiung dengan berjalan kaki, dan bagi yang mempunyai sepeda maka perjalanan ini lebih akan membantu. Dengan kondisi tempat pendidikan yang sangat jauh, maka bagi masyarakat yang ingin bersekolah harus tinggal atau kos di daerah Sitiung.

Sebahagian masyarakat Timpeh lebih memilih tidak bersekolah, selain karena jauhnya tempat pendidikan dan juga disebabkan oleh susahnya perekonomian masyarakat pada masa itu. Maka itu hanya beberapa orang saja yang mengecap bangku pendidikan. Pada umumnya masyarakat Timpeh sebelum datangnya masyarkat transmigrasi tidak bisa membaca dan menulis. Dengan datangnya masyarakat transmigrasi yang dimulai dari tahun 1982 tersebut, didirikan sekolah-sekolah. Sekolah pertama yang didirikan ialah Sekolah Dasar (SD), walaupun sekolah ini didirikan namun belum ada gedung khusus untuk sekolah ini, pendidikan dilaksanakan dirumah warga, sementara untuk tenaga pengajar diambil dari masyarakat transmigrasi yang bersedia untuk menjadi guru honor. Namun untuk sekolah SMP masyarakat juga harus bersekolah di Sitiung.

Semakin berkembangnya daerah Timpeh secara bertahap dan juga didukung dengan semakin membaiknya perekonomian masyarakat, maka didirikanlah beberapa sekolah dari berbagai tingkat yaitu, PAUD, TK, SDN, SMPN, SMAN, dan MAS. Data Bappeda dan BPS Darmasraya tahun 2011 
menyebutkan daftar sekolah-sekolah yang ada di kecematan Timpeh sebagai berikut:
1. PAUD
: 8 Buah
2. TK
: 8 Unit
3. SDN
: 11 Unit
4. SMPN
: 4 Unit
5. SMAN
: 1 Unit
6. MAS (SLTA) : 1 Unit

Adanya sarana pendidikan tersebut telah mengubah pandangan masyarakat terhadap pendidikan dan menyadari bahwa pendidikan merupakan hal yang sangat penting dalam kehidupan. Walaupun sebahagian besar masyarakat Timpeh bersekolah, namun tidak bisa dihindari ternyata masih banyak pemuda-pemuda yang tidak mau untuk bersekolah. Hal ini disebabkan oleh banyaknya pemuda Timpeh yang lebih tertarik untuk menjalankan usaha keluarganya dengan berkebun kelapa sawit, karena semenjak diadakan budidaya tanaman kelapa sawit telah membawa perkembangan dalam bidang perekonomian masyarakat Timpeh, sehingga tanpa bersekolahpun mereka bisa menghasilkan uang.

\section{Agama}

Agama merupakan salah satu struktur institusional penting yang melengkapi keseluruhan sistem sosial suatu masyarakat. Tetapi, masalah agama berbeda dengan masalah pemerintah dan hukum yang lazimnya menyangkut alokasi serta pengendalian kekuasaan. Berbeda juga dengan lembaga ekonomi yang berkaitan dengan kerja, produksi dan pertukaran, serta berbeda juga dengan lembaga keluarga yang hakikatnya mengatur hubungan antara jenis kelamin, antara generasi yang diantaranya berkaitan dengan pertalian keturunan serta kerabat (Salahuddin, n.d.).

Dharmasraya umumnya dan khususnya Kecamatan Timpeh merupakan daerah rantau dalam alam Minangkabau. Sistem kehidupan masyarakatnya tidak jauh berbeda dengan daerah-daerah Minangkabau lainnya. Pada umumnya masyarakat Timpeh beragama Islam. Meskipun data tentang jumlah penduduk menurut agama tidak dapat diketahui dengan pasti, namun dari beberapa informasi dapat diketahui bahwa pada umumnya masyarakat Timpeh adalah pemeluk agama Islam. dibuktikan dengan terdapat 3 buah masjid sebagai sarana tempat beribadah di daerah Timpeh saat itu, selain itu masjid juga digunakan untuk merayakan hari-hari besar Islam seperti isra' mi'raj, maulid nabi, dan tahun baru Islam. Sekali-kali juga diadakan wirid pengajian, dan lain-lain sebagainya. masjid didirikan disetiap pemukiman masyarakat.

Hasil penelusuran dari data kantor Kecamatan Timpeh menunjukkan bahwa tidak ada satupun masyarakat Timpeh yang memeluk agama lain kecuali Islam. Hal ini juga dapat ditinjau dari status pembuatan Kartu Tanda Penduduk (KTP) yang terdaftar bahwa seluruh masyarakat memeluk agama Islam.Namun dari hasil penelusuran sumber yang terpusat di kenagari memberikan informasi bahwa di Nagari Ranah Palabi tercatat 13 orang penduduknya memeluk agama Kristen. Sementara dari hasil wawancara dengan beberapa orang tokoh masyarakat menyatakan bahwa tidak hanya di Ranah Palabi, di Nagari Tabek juga terdapat beberapa orang Kristen, walaupun tidak ada pengakuan yang jelas dari yang bersangkutan. Hal ini membuktikan bahwa setelah datangnya masyarakat transmigrasi di daerah Timpeh mengalami perubahan dalam bidang keagamaan, salah satunya dengan munculnya agama Kristen di daerah ini, karena sebelum datangnya masyarakat transmigran, seluruh penduduk Timpeh beragama Islam.

Bagi masyarakat transmigran yang non Islam umat Islam Timpeh berusaha memberikan pengertian dan ilmu pengetahuan tentang agama Islam, sehingga beberapa orang di antaranya secara sadar pindah agama keislam. Beberapa orang diantaranya ada juga yang pindah agama karena terkesan dengan semangat persaudaraan masyarakat setempat (Minangkabau) sehingga memilih Islam sebagai agama. Selain itu perubahan terlihat dari segi pemahaman keagamaan, umumnya etnis Minang baik itu penduduk asli maupun transmigrasi menjalankan praktek keagamaan mereka lebih berpatokan kepada paham Ahlu Sunnah wal-Jama'ah sementara sebahagian besar penduduk transmigran yang berasal dari etnis Jawa dan Sunda mereka lebih berpatokan kepada praktek ormas Muhammadiyah. Sementara masyarakat setempat lebih pada ormas Tarbiyah. Perbedaan ini dapat dilihat dalam 
beberapa praktek keagamaan yang dilakukan oleh kedua golongan tersebut seperti perbedaan qunut dan tidak qunut. Pada umumnya masyarakat Timpeh adalah pengamalan shalat subuh memakai do'a qunut. Namun ada sebahagian kecil masyarakat Timpeh melaksanakah shalat subuh tanpa do'a qunut khususnya untuk Nagari Panyubarangan. Pemahaman ini muncul ketika masuknya ormas Muhammadiyah, setelah datangnya masyarakat transmigrasi. Sebelum adanya masyarakat transmigran ummat Islam di Timpeh menganggap Qunut adalah hal yang sangat ditegaskan untuk di amalkan. Selain itu, perbedaan mencolok dalam hal keagamaan juga dapat dilihat dari penentuan awal ramadhan dan idul fitri. Masyarakat muslim tradisional masyarakat Timpeh dalam penentuan awal-akhir bulan Ramadhan dan hari raya Idul Fitri tidak mengikuti pendapat imam (pemuka tariqat) sebagaiman halnya yang terjadi dibeberapa daerah lain. Penentuan awal-akhir Rhamadhan dan hari raya Idul Fitri berdasarkan ketetapan Kementrian Agama (pemerintah). Sekalipun ada beberapa di antara mereka yang menjadi anggota ormas keagamaan dan pengikut tarikat. Meski ada ormas yang menentukan awal-akhir Rhamadhan dan hari raya Idul Fitri berdasarkan ormas itu, namun mereka tidak mengikutinya.

Praktek keagamaan lain yang sering menjadi indikator perbedaan paham adalah shalat Tarawih. Dalam pelaksanaannya, ada yang melaksanakan dua puluh raka'at dengan satu salam pada setiap dua raka'at dan ada yang shalat delapan raka'at dengan dua raka'at satu salam. Selain itu ada juga yang melaksanakan shalat Tarawih delapan raka'at akan tetapi dengan satu salam pada setiap empat raka'atnya. Adapun yang melaksanakan 20 raka'at dengan satu salam setiap dua raka'at adalah masyarakat asli Kecamatan Timpeh. Hal ini berdasarkan pemahaman yang diajarkan oleh Buya Salam kepada mereka. Masyarakat yang melaksanakan shalat tarawih 20 raka'at, pada umumnya berasal dari Nagari Taratak Tinggi, Timpeh, Ranah Palabi, dan Tabek.

Sedangkan ummat Islam yang berada di Nagari Panyubarangan melaksanakan shalat Tarawih sebanyak delapan raka'at, dengan satu salam setiap empat raka'atnya.
Masyarakat panyubarangan pada umumnya adalah masyarakat transmigran asal Pulau Jawa. Pemahaman empat raka'at dengan satu salam bersandarkan hadis Nabi SAW. (Ibn Hajar al-Asqalani, tt, Juz; 7), yang mengatakan tentang shalat sunnah yaitu:

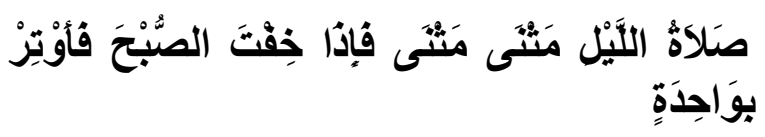

Artinnya: Dari Ibn Umar R.A berkata: Rasulullah SAW bersabda shalat malam itu dua-dua, jika kamu takut masuk waktu shubuh maka witirlah satu raka'at. H.R. Muttafaqun 'Alaih

Walaupun terjadi perbedaan dalam memaham praktek keagamaan namun kehidupan mereka dilandasi oleh sikap saling menghargai. Tidak bisa dihindari bahwa perbedaan ini tetap memberikan pengaruh kepada masyarakat sama halnya di daerahdaerah lain, seperti terkotak-kotaknya tokoh agama dan Mesjid dalam bentuk kelompok. Sehingga umumnya mereka shalat di Masjid yang diurus atau diimami oleh orang yang sama pemahaman keagamaannya dengan mereka.

Perkembanga yang sangat terlihat dalam bidang keagamaan ini ialah semakin banyaknya bangunan Masjid dan Mushalla yang didirikan tercatat sampai sekarang mencapai 57 bangunan, munculnya berbagai lembaga pendidikan Islam, seperti MDA, TPQ/TPSQ, Yayasan al-Muhajirin, dan pondok pesantren Miftahul 'Ulum mulai dari tingkatan Raudathul Adfal sampai tingkat Madrasah Aliyyah. Selain itu juga diadanya beberapa kegiatan pendidikan non formal seperti, wirid yasinan, remaja mesjid, dan majelis ta'lim. Semangat keagamaan masyarakat Timpeh juga dapat dilihat dengan semakin banyaknya masyarakat Timpeh pergi berhaji dan setiap bulan Ramadhan diadakan acara santunan untuk anak-anak yatim.

\section{Politik}

Masyarakat Timpeh sebelum datangya masyarakat transmigrasi masih hidup dalam kelompok kecil. Daerah Timpeh masih terdiri dari hutan belantara, hanya tiga kampung yang didiami oleh masyarakat yaitu, Timpeh, Tabek, dan Jao. Tiga kampung inilah yang 
dijadikan tempat pemukiman, setiap pemukiman didirikan masjid sebagai sarana tempat peribadatan, selain sebagai sarana tempat beribadah masjid ketika itu juga berfungsi sebagai sarana pendidikan Islam. Adapun rumah-rumah penduduk hanya terdiri dari pondok-pondok kecil atau rumahrumah panggung yang terbuat dari papan dan beratap rumbia.

Datangnya masyarakat transmigran ke daerah ini telah membuat sebahagian wilayahnya dipenuhi oleh penduduk dari berbagai etnis. Hutan-hutan ditebangi dan dijadikan sebagai tempat pemukiman dan lahan perkebunana. Datangnya masyarakat transmigrasi ini telah membawa sebuah perkembangan untuk daerah Timpeh, karena penduduknya semakin banyak, selain itu karena jauhnya daerah Sitiung sebagai ibukota kecamatan, maka muncullah inisiatif dari kalangan masyarakat untuk menjadikan Nagari Timpeh sebagai sebuah kecamatan.

Mekarnya daerah Timpeh menjadi sebuah kecamatan tidak bisa dipisahkan dengan mekarnya Dharmasraya sebagai sebuah kabupaten dari Kabupaten Sawah Lunto-Sijunjung. Kabupaten Dharmasraya lahir berdasarkan Undang-Undang No. 38 tahun 2003, tentang pembentukan kabupaten Dharmasraya diresmikan pada tanggal 7 Januari 2004. Sejak itu Dharmasraya terpisah dari kabupaten induknya, yakni SawahluntoSijunjung. Kabupaten Dharmasraya terbentuk dari empat kecamatan yang semula menjadi bagian Kabupaten Sawahlunto-Sijunjung, adapun kecamatan-kecamatan tersebut ialah, Pulau Punjung, Sitiung, Koto Baru, danSungai Rumbai.Sementara untuk sebuah kabupaten harus mempunyai beberapa kecamatan, maka dianjurkanlah untuk memekarkan nagari-nagari yang ada di dalam pemerintahan Kabupaten Dharmasyara menjadi sebuah kecamatan. Maka itu terjadilah beberapa pemekaran, sehingga kabupaten Dharmasraya menjadi 11 kecamatan

Rancangan pemekaran Nagari Timpeh menjadi sebuah kecamatan dimulai sekitar tahun 2005-2006. Adapun pelopor berdirinya Kecamatan Timpeh tidak bisa dilepaskan dari peranan, pemerintah setempat, Ninik Mamak, Alim Ulama, Cadiak Pandai, Bundo Kanduang, Tokoh Masyarakat, beserta Pemuda Nagari Timpeh. Karena usaha dari beberapa kalangan tersebut, maka terbentuklah kecamatan Timpeh. Sesuai dengan Peraturan Daerah Kabupaten Dharmasraya Nomor 3 tahun 2008, daerah Timpeh yang awalnya bahagian dari Kecamatan Sitiung berdiri secara resmi menjadi sebuah kecamatan pada tanggal 10 Desember 2008.

Setelah terjadi pemekaran kecamatan, maka daerah Timpeh yang awalnya terdiri dari dua kenagarian yaitu Nagari Timpeh dan Tabek, dimekarkan menjadi 5 kenagarian berdasarkan Peraturan Daerah Kabupaten Dharmasraya Nomor 4 tahun 2009 yang secara resmi menjadi 5 Nagari dan 21 Jorong pada tanggal 4 Desember 2009.

\section{KESIMPULAN}

Kabupaten Dharmasraya merupakan salah satu daerah tujuan transmigrasi di Pulau Sumatera. Beberapa daerah yang berada dalam Kabupaten Dharmasraya sebagai daerah tujuan transmigrasi di antaranya ialah daerah Timpeh. Program transmigrasi yang dijalankan di daerah Timpeh ini dilaksanakan sejak tahun 1982 sampai 1995.

Masyarakat Timpeh merupakan masyarakat yang terbuka dan mudah dalam menjalin hubungan sosial yang baik. Sehingga antara penduduk asli dan orang-orang transmigran tercipta hubungan persaudaraan yang kokoh, yang dibangun atas dasar identitas bersama secara budaya yaitu 'Minangkabau baru'. Baik masyarakat transmigrasi asal Pulau Jawa atau yang adatistiadatnya berlainan dengan adat Minangkabau maka semuanya menyesuaikan diri dengan adat Minangkabau. Semua warga transmigrasi menjadi anak kemenakan dari ninik mamak daerah dimana ditempati. Masyarakat transmigran dianjurkan mengaku induak (bersuku) kepada ninik mamak yang memimpin persukuan yang ada di daerah Timpeh. Interaksi yang terjadi dengan baik antara penduduk asli dan pendatang yang berbeda etnis, mengakibatkan terjadinya asimilasi budaya di daerah ini.

Program transmigrasi yang dilaksanakan oleh pemerintah telah membawa beberapa perubahan yang menunjukkan kepada kemajuan untuk daerah Timpeh. Sebelum datangnya masyarakat transmigrasi daerah ini masih terisolir karena daerahnya terdiri dari hutan-hutan, dan belum adanya pembangunan infrastuktur daerah setempat. 
Daerah Timpeh juga jauh dari Ibukota Kabupaten Dharmasyara.

Perubahan yang terjadi akibat asimilasi budaya tidak hanya pada bidang adat istiadat tapi juga pada bidang politik dan ekonomi. Perubahan dalam bidang politik ditandai dengan adanya pemekaran Kecamatan Timpeh pada tahun 2008 dari kecamatan Sitiung. Sementara dalam bidang ekonomi masyarakat transmigran yang dibekali dengan pengetahuan budidaya tanaman kelapa sawit mengakibatkan tumbuhnya perekonomian masyarakat transmigran sekaligus masyarakat setempat. Hidup secara multikultural telah membentuk masyarakat Timpeh menjadi masyarakat yang moderat dalam kehidupan keagamaan.

\section{DAFTAR PUSTAKA}

Asril. (2009). Perilaku Ekonomi Petani Kelapa Sawit dalam Pengelolaan Pendapatan Rumah Tangga di Daerah Transmigrasi Kecamatan Lubuk Batu Jaya, Kabupaten Indragiri Hulu-Riau. Universitas Negeri Padang.

BPS. (1984). Sumatera Barat Dalam Angka. Padang.

Budiman, A. (1985). Transmigrasi Di Indonesia; Ringkasan Tulisan Dan HasilHasil Penelitian. Jakarta: Gramedia.

Firdaus. (2012). Relasi Etnik dan Identitas Kewargaan di Kota Binjai. In H. Budiman (Ed.), Kota-Kota di Sumatra; Enam Kisah Kewargaan dan Demokrasi (pp. 133190). Jakarta: The Interseksi Foundation.

Firdaus. (2014). Protes Korban Bencana; Studi Konflik Penanggulangan Bencana di Pasar Raya Padang. Jurnal Ilmu Sosial
Mamangan, 1(2), 27-39.

Hardjono, J. (1982). Transmigrasi dari Kolonisasi Sampai Swakarsa. Jakarta: Gramedia.

Hasan, F. (1988). Dinamika Mayarakat dan Adat Minangkabau. Padang: Pusat Penelitian Universitas Andalas.

Kohar, W. (2010). Mediating Cross Cultur Theory; Teori Temuan dari Penelitian Etnografi Komunikasi Antarbudaya Era Otonomi Derah (Studi Mikro Induktif di Nagari Lunang Sumatera Barat). Innovatio, 9(1).

Mochtar. (1978). Transmigrasi Jawa Timur dari Daerah Rawan. Suara Merdeka.

Rahmad, D. (2015). Gaya Interaksi dan Integrasi Sosial Anak Muda Rantau: Kasus Mahasiswa Kost di Air Tawar Barat, Kota Padang. Jurnal Ilmu Sosial Mamangan, 4(2).

Salahuddin. (n.d.). Psikologi Agama. Jakarta: Rajawali Press.

Salmadanis, \& Samad, D. (2003). Adat Basandi Sarak': Nilai dan Aplikasinya Menuju Kembali ke Nagari dan Surau. Jakarta: Kartika Insan Lestrari Press.

Subangun. (1980). Dari Kolonisasi Hingga ke Resettlemenr, Melanjutkan Tradisi Kemiskinan Penduduk Pulau Jawa. Kompas, p. 4. Jakarta.

Suroso, D. (1981). Dari Kolonisasi Sampai Transmigrasi. Kompas, p. 4. Jakarta.

Swasono, S. E., \& Singarimbun, M. (1985). Sepuluh Windu, Transmigrasi di Indonesia (1905-1985). Jakarta: UI Press.

Warsito, R. (1984). Transmigrasi : Dari Daerah Asal Sampai Beturan Budaya di Tempat Pemukiman. Jakarta: CV. Rajawali. 